\title{
Духовна дипломатія
}

Spiritual Diplomacy

Володимир ДЕНИСЕНКО, доктор історичних наук, доцент, завідувач кафедри журналістики Інституту філології та масових комунікацій Відкритого міжнародного університету розвитку людини «Україна», член Національної спілки журналістів України

\section{ДЕРЖАВОТВОРЧІ ЗАСАДИ КИЇВСЬКОЇ РУСІ: ДУХОВНІСТЬ, ОСВІТА, ДИПЛОМАТІЯ (до 1030-річчя Хрещення Руси-України)}

Анотація. У статті автор характеризує особливості християнської культури, яка, на його думку, репрезентує духовне обличчя епохи. Узагальнює історіографічні згадки та літературні пам'ятки XI ст. Насамперед досліджує літопис Нестора Літописця, ченця Києво-Печерського монастиря, «Поучення» Володимира Мономаха. Окреслює спектр суспільно-політичних і релігійно-філософських проблем тогочасного суспільства. Реконструює шкільну систему освіти тогочасної доби.

Ключові слова: Київська Русь, християнство, культурне та духовне життя, церква, система освіти.

У науковій літературі є чимало напрацювань про культурне життя Київської Русі X-XIII ст. Варто згадати літописні свідчення про те, що Київська держава вже в середині IX ст. була добре зорганізована. Досить навести літописну згадку про Кия, який, за словами преподобного Нестора, «Ходив до Візантії й велику честь мав від царя візантійського» [1]. Міжнародне визнання відбулося за часів Аскольда. Його правління (загинув у 882 р.) стало блискучою сторінкою в історії ранньої Русі, коли молода держава вийшла на світову арену, здобувши загальне визнання і ствердивши себе як невід'ємну частину середньовічної ойкумени. Зазначимо, що за правління Аскольда до складу Київської Русі входили землі полян, деревлян, дреговичів та південно-західної частини сіверян (з містом Черніговом). На території проживали кривичі, в’ятичі, радимичі, сіверяни. 
Головні інтереси Аскольдової Русі охоплювали південь та південний схід. Його приваблювали багаті й сильні держави - Хазарія, Болгарія, Biзантія, кавказькі країни - Грузія, Вірменія, Албанія (Азербайджан), навіть віддалений Багдад, з якими було встановлено активні торговельні та політичні зв’язки [2].

Отож першим князем, який прийняв християнство, був Аскольд. Він з дружиною вирушив у черговий похід на Царгород. Події 860 року, як засвідчив Візантійський патріарх Фотій, склалися так, що захистити місто, окрім Богородиці, тоді не було кому, бо імператор з військом вирушив воювати з агарянами. Військо Аскольда оточило місто, здавалося, ось вже має бути перемога, але... патріарх Фотій молився про спасіння міста у церкві Влахернської Божої матері: ризу ікони Богородиці помістили у море. І трапилося чудо: піднялася буря, яка обрушилася на човни Аскольда. Той, вражений подією, разом з дружиною прийняв обіт хрещення. Якщо напад на Константинополь стався 18 червня 860 р., то обряд хрещення здійснено було наприкінці червня або на початку липня. А вже взимку 860-861 pр. в Русі запроваджено до вжитку переклади богословських книг: Євангеліє, Апостол та Псалтир. Тож ідеться про зародження давньоруської писемності, яка згодом набула широкого розвитку [3].

Однак через історичні обставини Русь залишалася впродовж десятиліть язичницькою. Лише згодом християнство прийняла княгиня Ольга, а потім країну хрестив іiі онук Володимир. Від своїх витоків українська церква перебувала у канонічній залежності від Царгородського патріарха, проте постійно намагалася позбавитись візантійської суперматії, хоч патріархи не втручались у справи української церкви, а лише висвячували і благословляли на кафедру руських митрополитів. Князі не завжди прихильно ставилися до митрополитів-греків, вони прагнули бачити першоієрархами українців - Іларіона та Клима Смолятича, а князь Ростислав попередив патріарха, щоб той не присилав своїх ставлеників на київську митрополію без княжої на те згоди. Держава послідовно дотримувалася політики унезалежнення від іноземних церковних впливів, що було логічним продовженням традиційного свободолюбства нашого народу.

Якщо візантійська церква повністю підпорядковувалася державній владі, а церква католицька мала зверхність над світською владою, то церква в Київській Русі обрала проміжне становище.

Під час обрання церковних ієрархів насамперед враховували звичаї і канони православної церкви. Князь разом із представниками церкви, народу обирав кандидата на єпископську кафедру і відсилав його до столиці, прохаючи київського князя й митрополита рукоположити на єпископа. Згідно з давніми правилами церкви таке обрання було законним. Якщо ж митрополит без погодження з місцевим князем ставив єпископа, то це 
вважали незаконним. Під час добору будь-якого святительського чину було недостатньо бажання князя та народної згоди, кандидат мав відповідати євангельським та святоотецьким вимогам до особи, покликаної на священство. У випадку розбіжностей у поглядах на кандидата, його обирали жеребкуванням. Монастирські братії також обирали собі ігуменів, що було започатковано ще у Печерському монастирі. Богослужби та треби відправлялися за одпрацьованими місцевими звичаями. Вірогідно, канонізація на Русі проходила також з ініціативи місцевих жителів, затверджувалася митрополитом і патріархом [4].

За трактуванням Патріарха Філарета, «Християнство створило духовну основу для єдності Давньоруської держави. Вплив Руської Православної Церкви в той період був значним. Церква зіграла величезну роль у припиненні міжусобиць князів, у об’єднанні князівств у єдиній державі та ії зміцненні, у закріпленні й розширенні зв’язків Київської Русі з багатьма європейськими державами, насамперед з Візантією та Болгарією. 3 прийняттям християнства на Русь перейшли наявні тоді на сході форми церковної організації. Руська держава переймала найвищі форми державної організації Візантії. Русь увійшла в родину європейських держав.

Про хрещення Русі оповідають різні літературні пам'ятки ХІ ст. До них насамперед належить Літопис преподобного Нестора, ченця Києво-Печерського монастиря, який ще називають Початковим літописом. Найдавніші, що дійшли до нас, списки його - Лаврентіївський та Іпатіївський сягають XIV ст. В основі літописного зведення три особливих цільних оповідання як головні його складові частини: 1) «Повість временних літ», доведена до 1054 р.; 2) «Сказання про хрещення Русі», датоване в літописі 986-988 рр., а складене на початку XII ст., і 3) Києво-Печерський літопис, в якому описані події XI-XII ст. до 1110 року включно.

Крім Початкового літопису $є$ ще кілька давніх літературних пам'яток XI ст., які описують хрещення князя Володимира і християнізацію Київської Русі. До них належить «Слово про Закон і Благодать», написане Київським митрополитом Іларіоном. Його творчість датують 1037-1050 pр. «Слово» дійшло до нас у списках XV і XVI ст. Після митрополита Іларіона чернець Яків написав «Похвалу князеві руському Володимиру». Його історичне свідчення має дуже важливе значення. Він був сучасником князя Ізяслава і писав близько 1070 р. Ченцеві Якову приписують і складання «Житія святого Володимира». Обидві ці пам'ятки були відкриті митрополитом Московським Макарієм (Булгаковим). До пам'яток давньоруської писемності належать також «Сказаніє об убієнії свв. Бориса і Гліба». Воно написане преподобним Нестором до 1072 р. [5].

Церква Київської Русі як суспільне творення сприяла національному об’єднанню і становленню руської державності. На основі єдності пра- 
вославної віри зросла й національна самосвідомість, де церковна єдність Русі передувала й національно-державному об’єднанню. Християнське населення Київської Русі, приходячи на богослужіння в християнський храм, чуло поминання митрополита всієї Русі і таким чином відчувало свій зв'язок з центром держави.

Проф. В.Й. Ключевський говорить: «На Київського князя прийшле духовенство переносило візантійське поняття про государя, поставленого від Бога не для зовнішнього тільки захисту, а й для установлення і підтримки внутрішнього громадського порядку» [6]. Князь мав здійснювати правосуддя, захищати ображених і карати злочинців. «Ти поставлений від Бога на кару злим, а добрим на помилування», - говорили єпископи князеві Володимиру [7].

Окреслюючи спектр суспільно-політичних і релігійно-філософських проблем сучасного суспільства, варто звернутися до періоду християнства Київської Русі. Прийняття Руссю візантійського християнства зробило Київ одним з найкрасивіших, багатих і культурних міст Європи. Київ за часів Ярослава справді вважали культурним центром Європи. Західні мандрівники захоплювалися його величчю. Європейські монархи вважали за честь породичатися з Київським великокнязівським родом. Про красу і велич Києва залишилися неупереджені висловлювання іноземних гостей, які відвідували столицю. Єпископ Дитмар Мерзебурзький (974-1018 рр.) писав, що в Києві мешкало багато іноземців, було вже близько 400 церков і 8 ринків. Велика пожежа 1070 року знищила вже 700 церков. Уже одні ці скупі цифри показують, якими темпами будувались і прикрашались храми. Адам Бременський, описуючи велич київських палат, вважав Київ суперником Константинополя. Сучасний бельгійський історик Жак Піренн говорить: «Новгород-Київська держава в Х ст. була цивілізованим центром континенту».

3 прийняттям християнства Русь стає повноправною учасницею світового історичного процесу і культурної візантійської традиції. Усвідомивши себе спадкоємицею великої та освіченої Візантії, Русь фактично заступила ії місце у православному християнському світі, поклавши на себе місію виконувати роль сполучної ланки між Сходом і Заходом [8]. У XII ст. на письмі з'явилася назва «Україна», яка означала «край», «земля», «країна». У Київській Русі завершилося формування українського народу за головними етнічними ознаками. У цьому й полягало одне з історичних значень Київської Русі в історії українського народу.

У Київській Русі з'являються зовнішні атрибути української державності: грошова одиниця - гривня і державний знак - тризуб. Вони так вкорінилися в історичну пам'ять українців, що збереглися у ній протягом майже тисячоліття. Закономірно, що ці державні знаки Київської Русі 
відродилися в атрибутиці сучасної Української держави. Існування держави сприяло прискоренню зміни суспільної організації населення. На зміну родовому ладу прийшла сільська община з суворою регламентацією господарських і суспільних відносин. 3 того часу вона продовжувала визначати життя селян протягом багатьох століть. 3'явилася спільна для слов'янських народів писемність, що упродовж багатьох століть була однією з основ їх етнічної близькості. У Київській Русі було започатковано школи, бібліотеки, камінне будівництво тощо.

Історичне значення мала Київська Русь у розвитку міжнародної торгівлі. Завдяки централізованій політиці вона виходить на міжнародну арену як важливий торговий партнер, веде активну торгівлю з Болгарією, Чехі$є ю$, Угорщиною, Візантією, Німеччиною, Норвегією, Швецією, Францією, Англією. Тісні торговельні зв'язки підтримувала вона і з країнами Закавказзя, насамперед Грузією та Вірменією. Активна торгівля була з країнами Сходу. Київська Русь відігравала одну з провідних ролей у європейській і близькосхідній історії. Вона підтримувала дипломатичні відносини з низкою європейських держав і активно впливала на європейську історію. Встановилися тісні династичні зв’язки руських князів з візантійськими та європейськими дворами. Одна з доньок Ярослава Мудрого була заміжня за французьким, друга - за норвезьким, третя - за угорським королем. Митрополит Іларіон писав в одному з своїх творів, що Київська держава «знана і чута всіма сторонами землі» [9].

Життя всередині всесвітнього організму церкви було благодатним для формування національної свідомості молодої Русі [10]. Слов'янська традиція Кирила і Мефодія створила вчення про національне покликання держави. Стосовно Києва не можна говорити про існування подібного російському месіанства в значенні винятковості національного релігійного покликання [11]. Всі народи покликані Богом, і Русь серед них. Це всесвітній, екуменічний, а не націоналістичний погляд.

3 іншого боку, нація не остання категорія в Царстві Божому. Як кожна людина має постати перед Богом, відповідаючи за своє життя, так мають стати перед Богом всі народи як духовна цілісність, зі своїми гріхами і своєю святістю, в земній Церкві й у вічності. Ця релігійна концепція нації не могла розвинутися на середньовічному Заході при єдності його латинської культури [12]. Вона бере свій природний початок у Східній церкві 3 іiі множинністю мов і культур: близькосхідної, грецької, слов’янської. Не треба забувати, що латинський світ у свідомості Русі XI ст. також входив до християнського універсуму, хоч і не займав у ньому центрального місця. «Багато які останні стануть першими». Та ж національна ідея лежить в основі культу страстотерпців. Борис і Гліб «зняли ганьбу з синів Русі», тобто ганьбу застарілого язичництва [13]. У ті віки ніхто на Русі не сприй- 
мав свою країну як центр християнського світу або як країну найправдивішої віри і найбільших святих. Св. Дмитрій Солунський, великий захисник свого міста від слов'янського вторгнення, став одним з найбільш шанованих на Русі святих. Київська Русь створила нове свято, невідоме грецькій Церкві, в пам'ять про порятунок молитвами Богоматері Константинополя від слов'янської облоги і святої Покрови. і це свято виявилося в числі найбільш любимих українським народом, хоч його історичним ядром була перемога греків над слов'янами. Можна стверджувати, що під керівництвом грецького патріарха і митрополитів молода Церква змогла розвинути глибоку національну самосвідомість, повністю вільну від гонористого націоналізму. У період правління Ярослава Мудрого церковні ієрархи, порівнюючи тогочасний розквіт з язичницьким минулим, сповнюються благочестивої радості і захоплення [14].

Доречно посилатися на сучасні узагальнення першого міністра освіти, президента Відкритого міжнародного університету розвитку людини «Україна», академіка Петра Таланчука: “Був час, коли ми не думали, чи йти нам у Європу, - ми цю Європу правили” (Андрій Ганус). Син Анни Ярославни - король Франції Філіп I був королем 48 років, вона ж, давши бездітному королю-вдівцю спадкоємця, забезпечила правління династії Капетингів на 268 років. А загалом двадцять два королі Франції, які правили майже вісім століть, є потомками дочки князя Ярослава Мудрого. Цікаво, а чи знають про це сучасні французи?!

Київська держава займала територію від Балтійського моря на півночі до Чорного на півдні, від р. Сян на Заході до Волги та Оки на Сході. Дивлячись на сьогоднішню ситуацію в Україні, ми бачимо, що експансію Москви не можна зупинити постійними здачами інтересів українців. Безідейній московській орді можна протиставити тільки ідею. Для цього необхідно зруйнувати облудний московський міф про спільне походження українців, московитів і білорусів» [15].

Виникнення шкільництва в Київській Русі, яка набувала статусу геополітичної держави-імперії, зумовлене насамперед нагальною потребою суспільного життя. Як писав М.С. Грушевський, «...запотребування в людях письменних було велике, не тільки для справ церковних, але і для практичного діловодства [...] попит на писарів і рахунковців в адміністрації княжій, в господарстві боярській, в діловодстві купецькім мусив наростати дуже швидко, мабуть, ще задовго до Володимирової християнізації [...] писар-рахунковець був неодмінним товаришем княжих мужів, які їздили збирати вири і всякі дані на князя. Поруч того, теж здавна, були потрібні люди для роботи, так би сказати, секретарської. 3 другого боку, розмноження церков і монастирів вимагало великих мас книг для богослужіння, для читання в церквах, трапезах і т.д. Тодішнє списування 
вимагало багато часу і праці, і можемо собі уявити, скільки мусило займатись виготовленням хоч би найпотрібніших книг» [16].

Згідно з літописною пам’яткою «Повість минулих літ» зафіксовано відкриття першої школи в Київській Русі князем Володимиром 988 року: «Послав князь збирати у кращих людей дітей і віддавати їх у книжну науку» [17]. Напевно, йшлося про заходи культурного виховання вищих верств, опанування ними візантійської освіти й книжності, а також виховання освічених людей для політичної діяльності, потреб княжого двору і вищої ієрархії [18]. Запровадження князем Володимиром початків шкільної освіти мало безперечне значення для навчання вітчизняних книжників [19]. У «Повісті минулих літ» зазначається факт навчання книжної науки. Варто визнати, що спроба просвіти книгою негативно і навіть вороже сприймалася носіями язичницького світогляду. Літопис писав: «А матері плакали за чадами своїми, як за померлими, бо ще не були кріпкі у вірі» [20]. I все ж маємо великий позитив у починаннях князя Володимира. Бо ж прилучення до книжності давало змогу давньоруській суспільності безпосередньо опановувати надбання всесвітньої християнської культури. І неабияку роль перебрало на себе християнство як «релігія письма» $з$ притаманною ій побожною шаною до слова писаного, книжного. «Культура Київської Русі, - стверджує філософ В.С. Горський, - завдяки християнству набирає “книжного” характеру, відіграє роль могутнього каталізатора, що прискорював перебудову всієї суспільної свідомості» [21].

Безперечно, створені князем Володимиром школи закладали грунт для цього процесу, стимулювали його із суто практичною метою. Держава, яка потрапила в християнську цивілізацію, мусила мати комунікативні механізми для вербального спілкування [22]. Заглядаючи наперед, можна говорити, що відтоді розпочинається формування й давньоруського інтелігента. Не випадково, аналізуючи стан розвитку писемності у Х столітті, історик В.О. Ключевський писав: «Щойно поміж нас почало утверджуватись уміння читати й писати, як разом з ним з'явилися і книжки, а разом з книжками прийшла до нас книжна мудрість. Тоді руський розум припав жадібно до книг, до цих "річищ, населяючих Всесвіт, цих ісходищ мудрості”. Відтоді за розумного й тямущого чоловіка в нас почали вважати чоловіка “книжного”, тобто такого, що має науково-літературну освіту... Отак зродився перший достеменно відомий з письмових пам'яток тип руського інтелігента» [23].

Отже, оглядаючи заходи князя Володимира щодо впровадження шкільництва і його просвітницьку діяльність, несподівано відкривається надзвичайно цікавий ракурс, що виявляє нові грані в арсеналі педагогічної освіти давньої української держави [24]. Традиції батька наполегливо впроваджував Ярослав Мудрий. Приїхавши до Новгорода, він зібрав 
триста дітей старост та священиків і звелів їх учити книгам [25]. Отже, як зазначає М. Грушевський, існування в житті широкої потреби в письмі, з одного боку, велика письменська спадщина з другого, дають нам оптимізм у розвої старої освіти, книжності і шкільництва [26]. Цьому, певним чином, сприяв ще й той факт, що при митрополії, при більших княжих дворах і двірських церквах, монастирях були певного роду наукові інститути - бібліотеки, створені Ярославом, його сином Святославом, внуком Володимиром Мономахом, правнуком Святошею-Миколою.

На думку вітчизняних істориків, тогочасні школи облаштовували на візантійський взірець. Наступний етап - опанування чужих мов. Згадаймо, Мономах ставить своїм дітям взірець свого батька, який «удома сидячи, зумів знати п’ять мов, - за се честь єсть од інших країв» [27].

Мабуть, не тільки купці й мандрівники вважали за потрібне знати мови, але й на місцях мали бути люди, призначені для порозуміння з приїжджими чужоземцями, підтримуючи гідність своєї держави мали спілкуватися іноземною мовою з послами та княжими гостями. Надавалася перевага знанню грецької, латинської, німецької, угорської, половецької, варязької мов [28]. Вінцем ученості було опанування правил риторики, поетичного стилю та віршування.

Час князювання Володимира Мономаха був епохою могутності та слави. Тому, оглядаючи через плин століть давні події, історик має пам'ятати, що він не літописець: «останній дивиться передусім на час, а перший - на властивості і зв'язок діянь; може помилитися в розподілі місць, але повинен чітко визначити усьому своє місце» [29]. Безперечно, зародження писемності в Україні сягає ще дохристиянських часів. Історичні дослідження підтверджують, що договір Олега написаний болгарською мовою, але складений у Києві, а договір Ігоря слов'янською мовою [30].

Поширення християнства сприяло широкому розповсюдженню освіти у давній Русі-Україні. І хоча історія шкільництва того періоду ще як слід не вивчена, є підстави, посилаючись на літописні згадки, стверджувати про велику увагу до цієї справи київських князів. За свідченнями митрополита Климентія (XIII ст.), на Русі майже 400 осіб володіли грецькою мовою, а в «Збірнику кн. Святослава» 1073 року знаходимо опис стилю і риторичних фігур проповідницьких казань [31].

Перші школи були при кафедральних церквах, де служило переважно освічене духовенство. Облаштовували школи й у монастирях. Як правило, ними опікувалися ієрархи, здебільшого освічені греки, які посідали єпископські кафедри. Основою вищої духовної науки була грецька мова [32]

I це цілком виправдано, адже загальновідомо про давні взаємини східних слов'ян і візантійців. Однак у давньоруській державі сліпо не копіювали візантійські школи. Враховуючи, що грамотність була відома задов- 
го до Володимира, з появою християнства запроваджувалося так зване «книжне вчення» [33], в основу якого лягла програма візантійської освіти, яка будувалася на «семи вільних мистецтвах». Обсяг знань шкіл «книжного вчення» складався з традиційного комплексу предметів. Про це зазначав польський історик XV століття Ян Длугош, польський історик і поет Мацей Стрийковський у своїй «Хроніці польської, литовської, жмудської та всієї Русі». Про те, що в придворній школі Володимира вивчали грецькі листи, згадується у «Житії Бориса і Гліба», є свідчення про обізнаність вихованців із візантійською та чеською агіографічною літературою - житіями святих. Як зафіксовано у «Повісті минулих літ», у школі ознайомлювали 3 «Промовою філософа», яка давала основи богослов'я, складовими частинами якого в ті часи були філософія і діалектика [34].

Центром релігійного та культурного життя Києва, а отже, і всієї держави, була Десятинна церква, при якій, найімовірніше, й функціонувала придворна школа Володимира, одна з найбільших у тогочасній Європі. Літопис повідомляє: «Князь великий Володимир собрав детей 300, вдал учити грамоте» [35]. Школи «книжного вчення» готували своїх вихованців до діяльності в різних сферах державного, культурного та церковного життя. Син Володимира Ярослав доклав зусиль, щоб створити вищий навчальний заклад у збудованому ним Софійському соборі у 1037 році: «...собра писце многы и перекладаше от грек словенское письмо и исписаше книгы многы» [36].

На думку В.М. Татищева, «Ярослав зібрав багато перепищиків для перекладу книг з грецької на слов'янську мову, також наказав скласти багато книг для навчання» [37]. Отже, можна стверджувати, що князь подбав і про навчальні посібники. Російський історик Б.О. Рибаков висловлює припущення, що до викладання піснетворчості у княжій школі могли залучати «віщого» Бояна. Він навчав віршуванню майбутнього норвезького короля Гаральда, який склав пісню на честь своєї дружини, дочки Ярослава, Єлизавети [38]. Про міжнародний розголос про школу Ярослава Мудрого засвідчують такі факти: при дворі князя виховувалися англійські королевичі Едвін і Едуард, майбутні норвезькі конунги Гаральд і Ренгвальд, майбутній король Данії Магнус Добрий, угорський королевич Андрій та його брат Левенте, данський королевич Герман та інші іноземці знатного походження [39].

Переконливою ілюстрацією щодо наукового рівня придворної школи є перелік творів, які знаходилися у бібліотеці: «Богослов’я» Іоана Дамаскіна, «Шестиднев» Екзарха, «Християнська топографія» Косми Індикоплова, історична хроніка Георгія Амартола. Отже припущення існування «академії Ярослава», висловленого Михайлом Грушевським, мають логічні підтвердження [40]. 
У XI-XII століттях школи грамоти виникають в інших обителях. Згідно з писемними свідченнями та археологічними матеріалами у XII-XIII століттях монастирські школи існували майже в 60 містах [41]. Окрім шкіл «книжного вчення» відома була ще одна форма навчання - кормильство (від слова «корм» - пожива). Воно відоме майже в усіх народів ранньосередньовічної Європи [42]. Літописи розповідають, що кормильців-вихователів мали князі Ігор, Святослав, Ярослав Мудрий, Роман Галицький, Юрій Долгорукий та ін. Кормильцями княжат були бояри. 3 поширенням грамоти князі шукають освічених і морально досконалих наставників своїм дітям, надаючи їм статус домашніх педагогів [43].

Цікаву, досить вірогідну картину підготовки дітей до шкільного навчання на основі етнографічних даних відтворив у своєму дослідженні «Церковно-народный месяцеслов на Русі» I. Кослинський (Записки Русского Географического общества. - Т. VII. СПБ. - 1877) [44]. Знайдені археологами берестяні грамоти XII ст., які належали учню Онфіму, засвідчили, що запам'ятовування здійснювалося за прямим буквенним рядом [45]. Для кращого вивчення буквиці вдавалися до використання віршів релігійного змісту, в яких кожний новий рядок розпочинався наступною літерою абетки. Широке використання в тодішній шкільній практиці набув акровірш «Аз єсмь всему миру свет». Акровірші, ймовірно, використовувалися для читання слів, речень, виконували функцію молитов і відомі в літературних джерелах під назвою азбуки-літиц [46]. Цікавий факт заучування літер навів Б.О. Рибаков, який 1957 року під час розкопок у Любечі на Чернігівщині знайшов пряслице з надряпаними буквами А, Б, Г, Д, Е, Ж, 3. Певно, учениця, займаючись прядінням, час від часу повертала вгору пряслице веретена і перевіряла себе, як запам'яталася та чи інша літера [47].

Отож правомірне твердження В. Біднова, що «давні українські вчителі (iз кліру), підручники (церковно-богослужбові книги) та характер тодішньої освіти (так само як у Візантії та на Заході) зв'язували українську школу з церквою, тому парафіяльні храми, монастирі та єпископські кафедри були тими осередками, де містилися школи» [48].

При обмеженості пам'яток, які дозволяють говорити про поширення грамотності серед жіноцтва в XI-XIII століттях, маємо докази, що жіночій освіті було приділено значну увагу. Як зазначає Іван Огієнко, «жіноча освіта на той час в Україні була дуже мала,.. але помалу постають у нас і школи, звичайно, як початкові. 1086 року ігуменя Анна заклала в своєму монастирі дівочу школу - це перша дівоча школа в Україні. Звичайно, це була початкова школа - Анна навчала дівчат читати, писати, співати в церкві, навчала й жіночих ремесел» [49]. Автор підсумовує: «Треба думати, що великий князь Київський Всеволод, побудувавши церкву й монастир зі школою при ній, добре іï забезпечив, давши на їх утримування за звичаєм часу, відповідні 
маєтки. Пізніше опікуном цього родинного культурного центру Всеволодичів став старший син його, великий князь Володимир Мономах. I монастир, і жіноча школа, треба думати, добре виконували своє завдання» [50]. Заснування першої дівочої школи в Києві мало велике духовне значення. «А якщо хто з вірних побажає віддати дітей на навчання, то пресвітери не мають відмовити їм і не вимагатимуть платні за це, виключаючи, що самі батьки принесуть з доброчинності та доброї волі» [51].

Виникає запитання, а чого навчали у перших школах? Просвітитель князь Володимир прагнув, щоб книжне учення насамперед слугувало більшому розумінню християнської віри. Тому навчання мало за основу християнське церковне тлумачення для ліпшого розуміння віри й утвердження в ній і спрямовувалося для читання божественних книг. Але за своїм обсягом книжне учення було неоднорідним. Для дітей княжих, боярських Володимир бажав, щоб окрім початкових основ вони отримували, як і у Візантії, вищу освіту, яка б давала розуміння про владу як божественний вияв, історію від створення світу, основи географіі. Зазначимо, що сини Володимира були досить освіченими людьми. Ярослав знав добре грецьку мову, а його син Святослав захоплювався книгами, а Всеволод розмовляв п'ятьма мовами. Ймовірно, що Володимир у своїх далекосяжних планах у майбутньому прагнув мати руських за походженням високоосвічених ієрархів. Приклад цього - Київський митрополит Іларіон, який освіту здобув ще при володарюванні Володимира.

Навчання письму в давніх школах вимагало зосередженості, вправності. Як зазначав літописець Нестор, «Велика користь від книжного вчення. Книгами навчаємося мудрості, покаянню, стриманню; книги - це ліки, що наповнюють всесвіт, це вихідна мудрості, ними заспокоюємося у горі, вчимося глибокому розуму. Хто читає книги, той розмовляє з Богом» [52].

До пам’яток давньої педагогічної освіти належить літературна спадщина визначного державного діяча, великого київського князя Володимира Мономаха. Особливе місце посідає «Поучення», яке є найвидатнішим твором письменства Київської Русі. Про його автора Володимира-Василія Всеволодовича Мономаха (1053-1125) - сина Всеволода Ярославича, онука Ярослава Мудрого і водночас онука по матері візантійського імператора Костянтина IX Мономаха (від якого й дістав своє прізвисько) історик Микола Костомаров писав: «Поміж давніми князями дотатарського періоду після Ярослава ніхто не залишив по собі такої гучної і доброї слави, як Володимир Мономах, князь діяльний, сильний волею, що вирізнявся здоровим глуздом посеред своєї братії, князів руських. Довкола його імені обертаються майже всі важливі події руської історії у другій половині XI [53] та в першій чверті XII століття. Ця людина може по справедливості назватися представником свого часу» [54]. 
Володимир Мономах мав відповідне виховання, здобув на ті часи високу й різнобічну освіту. Князя вважали активним державним діячем, він організував кілька переможних походів проти лютих ворогів Київської Русі - половців, підтримував духівництво, яке тоді було основним носієм і популяризатором грамотності, сприяв розвиткові літописання. Як керівник великої держави користувався авторитетом у Візантії і на заході Європи. Час його великого князювання в Києві - період добробуту і піднесення Київського князівства. Проводячи обачливу політику, зумів зосередити у своїх руках і свого роду майже три чверті руських земель. Князь залишив після себе добру пам'ять, повагу сучасників і нащадків. Недарма Іпатіївський літопис образною художньою мовою описує жалісну вістку про смерть любимого в народі князя: «Преставися благоверный князь, христолюбивый и великий князь всея Русі, Володимер Мономах, иже просвіти Рускую землю, акы солнце луча пущая; его же слух произиде по всим странам, наипаче же бе страшен поганым, братолюбец, и нищелюбец, и добрый страдалец за Рускую землю... Святителе же жалящеси плакахуся по святом и добром князи, весь народ и вси людие по нем плакухуся, яко-же дети по отцю или по матери...» [55].

Епоха Володимира Мономаха - час розквіту художньої та літературної творчості середньовічної України-Русі. У Києві та в інших містах споруджувалися і прикрашалися живописом нові кам'яні церкви. До цього періоду належить складання первинного літопису, який з різних уривків і фрагментів з'єднав ігумен Сильвестр (близько 1115 року). «У числі творів, як зазначав Микола Костомаров, - які увійшли в його звід, було і писання літописця Печерського монастиря Нестора, через що весь Сильвестрів літописний звід носив потім у вченому світі назву Несторового літопису, хоч і неправильно, бо далеко не все в ньому написане Нестором і до того ж не все могло бути писане однією лише людиною» [56]. Зазначимо, що Володимир Мономах був ще й майстром слова. Літературна спадщина київського князя дійшла до нас трьома творами - «Поученням», «Грамоткою» (листом) до князя Олега Святославича та «Молитвою», і належить до найвидатніших пам’яток писемності Київської Русі-України [57].

«Поучення» Володимира Мономаха - цікавий твір і для сучасного читача. 3 нього можна дізнатися не лише про мислення великого діяча Київської Русі, його дидактичні погляди, але й про тогочасний світогляд, розуміння сутності життя, традиції, врешті побут [58]. Науковий аналіз про життєвий, педагогічний і державний досвід Володимира Мономаха подав дослідник Микола Чубатий у своїй грунтовній праці [59].

Вплив християнства на національну духовність здійснюється насамперед через сприйняття слова. Бо у Євангелії від Іоанна сказано, що «Споконвіку було Слово, і Слово було у Бога, і Слово було Бог». Розкриваючи 
роль духовного розвою періодичними виданнями православної преси, позитивно відзначив Патріарх Київський і Всієї Русі-України Філарет науково-довідкове видання із систематичним покажчиком змісту журналу «Киевские епархиальные ведомости» (1861-1918) [60].

Духовність - середовище, в якому може існувати і розвиватися суспільство у просторі й часі. А освіта є рушієм, носієм знань, а отже, сприяє формуванню духовності. Так стисло можна охарактеризувати зміст монографії автора цих рядків «Духовна освіта в Україні X-XVIII ст.»[61]. Підсумовуючи, можна стверджувати, що сформована у давньому Києві шкільна система сприяла подальшому розвитку освіти [62], а церква була в ті часи «осередком народного виховання і освіти» [63], і що «церковний характер шкільної освіти зберігався на Україні аж до кінця XVI ст.» [64].

Безумовно, історичний досвід здобутків християнського життя Киїської Русі неодмінно слугуватиме розвитку суспільних та релігійних відносин на сучасному етапі. Створення єдиної помісної Православної церкви - одна з національних цілей України. Питання про це поставила ще наприкінці 1918 року Директорія УНР на чолі із Симоном Петлюрою. 1 січня 1919 року прийнято Закон про автокефалію Української церкви.

Вивчення державно-церковних відносин неможливе також без урахування особливостей основоположних підходів до цього феномена з боку світських та конфесійних наукових кіл. Адже саме вони формують уявлення про розуміння проблеми церквою і державою ступеня інституційної специфіки суб’єктів державно-церковних відносин, виникнення можливих взаємозалежностей між ними, рівня їхнього автономізму, характеру впливу на суспільство, обсягів їхньої власної компетенції та сегментів спільних інтересів.

Тільки сукупність цих та інших знань здатна скласти уявлення про сучасні моделі державно-церковних відносин, визначити їні слабкі та сильні сторони, а також шляхи вдосконалення відносин між державою і Церквою з метою зміцнення людських свобод, розширення партнерських взаємин між ними заради побудови громадянського суспільства та подальшого утвердження демократії [65].

На завершення слід висловити побажання, що кількість вітчизняних науковців, котрі предметно студіюють українську релігійно-філософську думку XI-XV ст., для такої багатомільйонної держави, як Україна, мізерна.

1. Могильницька Г. Хроніка великого ошуканства. - Київ, 2009. - 96 с.

2. Брайчевський М.Ю. Літопис Аскольда. - Київ: Український Центр духовної культури, 2001. - 132 с.

3. Там само. - С. 102.

4. Бондар С. Українське православ'я X-ХІІІ століть і християнський світ доби Середньовіччя // Духовні студії. Київ, 2010. № 1, квіт.-трав.-черв. - С. 39-46.

5. Патріарх Філарет. Статті. Доповіді. - Т. 4. - К., 2002. - С. 434-435.

6. Ключевский В.И. Сочинения. Курс Русской истории. - Т. 1. - Москва, 1956. - 226 с. 
7. Патріарх Філарет. Статті. Доповіді. - Т. 4. - К., 2002. - С. 494-495.

8. Там само. - С. 537.

9. Борисенко В. Київська Русь в Історії України // Історичний календар. - К., 2001. - С. 91-93.

10. Реєнт О., Лисенко О. Українська національна ідея і християнство. - Київ, 1997. - 41 с.

11. Річинський А. Проблеми української релігійної свідомості. - Київ, 2000. - 382 с.

12. Религиозное и национальное в духовном и культурном наследии: Сб. ст. - Москва, 1991. - 66 с.

13. Лихачев Д. Великое наследие и классические произведения литератури Древней Руси. - Москва, 1979. - 239 с.

14. Черкасова Л. Релігійна свідомість давньої Русі: київське християнство X-XIII ст. // Історія релігій в Україні: Праці XI міжнародної наукової конференції. - Кн. 1. - Львів: «Логос», 2001. - С. 448-454.

15. Таланчук П. Тернистий шлях до незалежної України: публіцистика. - Київ: Університет «Україна», 2016. - 100 с.

16. Грушевський М.С. Історія української літератури: В 6 т., 9 кн. - Т. 2. - Київ: Либідь, 1993. - С. 27-29, 76; Т. 3. - С. 31.

17. Повість минулих літ: літопис / пер. В.С. Близнець. - Київ: Веселка, 1982. - 78 с.

18. Грушевський М.С. Історія української літератури: В 6 т. 9 кн. - Т. 2. - Київ: Либідь, 1993. - С. 27-29, 76; Т. 3. - С. 31.

19. Денисенко В. Книгодрукування в Україні // Історичний календар. - Київ, 2010. - С. 161-162;

20. Семенников В. Литературная и книгопечатная деятельность в провинции в конце XVIII и в начале XIX веков. - 1911. - Кн. 6. - С. 28.

21. Повість врем'яних літ. - Київ, 1990. - С. 29, 185.

22. Горський В.С. Святі Київської Русі. - Київ: Абрис, 1994. - 82 с.

23. Денисенко В. Освіта і шкільництво у давній Руси-Україні // Пам'ять століть. - 2005. - № 3-4. - С. 15-24.

24. Ключевский В.О. Неопубликованные произведения. - Москва: 1983. - С. 300-341.

25. Денисенко В. Перші школи в Київській Русі як чинник релігійної освіти // Науковий часопис Національного педагогічного університету імені М.П. Драгоманова. - № 3. - Київ, 2006. - (Серія 6. Історичні науки).

26. Грушевський М.С. Історія України-Русі: в 11 т., 12 кн. / [редкол.: П.С. Сохань (голова) та ін.]. - К.: Наукова думка, 1996. - Т. 9, кн. 1-2. - С. 1373.

27. Грушевський М.С. Історія української літератури: В 6 т. 9 кн. - Київ: Либідь, 1993. - Т. 2. - С. 27-29, 76; Т. 3. - С. 31.

28. Мономах В. Поучення / Володимир Мономах. - Київ: Пам'ятки України, 1986. - 31 с.

29. Грушевський М. С. Історія української літератури: В 6 т. 9 кн. - Київ: Либідь, 1993. - Т. 2. - С. 27-29, 76; Т. 3. - С. 31.

30. Карамзин Н.М. Сочинения: В 2 т. - Т. 2. - Ленинград: Художественная литература, 1984. - С. 238-239.

31. Холмський I. Історія України / Іван Холмський. - Мюнхен, 1949. - 103 с.

32. Семчишин М. Тисяча років української культури: історичний огляд культурного процесу. - Нью-Йорк; Париж; Сідней; Торонто, 1985. - 57 с.

33. Крип'якевич І. Історія української культури. - Вінніпег: Вид-во Івана Тиктора, 1964. - Т. 1. С. 73-74, 117-129.

34. Греков Б.Д. Культура Киевской Русі. - Москва; Ленинград, 1944. - С. 51-52.

35. Полное собрание русских летописей. - Т. 1. - С. 84-85, 152; Т. 16. - С. 31.

36. Там же. - T. 1. - C. 84-85, 152; T. 16. - С. 31.

37. Там же.

38. Семчишин М. Тисяча років української культури...

39. Рыбаков Б.А. «Слово о полку Игореве» и его современники. - Москва, 1971. - 74 с.

40. Пашуто В. Т. Внешняя политика Древней Русі. - Москва, 1968. - С. 134, 310.

41. Грушевський М. Три академії. - Київ: Київські збірники історії і археології, побуту і мистецтва, 1931. - 36. 1. C. 11-14.

42. Бабишин С.Д. Школа та освіта Давньої Русі. - Київ, 1975. - С. 9 -24.

43. Гардаков В.К. Кормильство в Древней Руси // Советская этнография. - 1970. - № 4. - С. 44-59.

44. Котляр Н.Ф. Древня Русь и Киев в летописных преданиях и легендах. - Київ: Наукова думка, 1986. - 160 с.

45. Кослинский И. Церковно-народный месяцеслов на Руси // Записки Русского Географического общества. СПб., 1877. - Т. VII.

46. Арциховский А.В. Берестяные грамоты мальчика Онфила // Советская археология. - № 3, 1957. - С. 215-223.

47. Бабишин С.Д. Школа та освіта Давньої Русі. - Київ, 1975. - С. 9 -24.

48. Рыбаков Б.А. Раскопки в Любече в 1957 г. / Б.А. Рыбаков // Краткие сообщения Института истории материальной культуры. - Вып. 79. - 1960. - С. 39.

49. Біднов В. А. Школа і освіта на Україні // Українська культура: лекції за редакцією Дмитра Антоновича / упоряд. С.В. Ульяновська; вступ. стаття І.М. Дзюби. - К.: Либідь, 1993. - С. 31-45.

50. Іларіон, митрополит (Іван Огієнко). Життєписи великих українців / Іларіон, митрополит (Іван Огієнко). - Київ: Либідь, 1999. - С. 78-79, 605.

51. Там само.

52. Малышевский И. Великий князь Владимир Святой, как первый учредитель школ в России // Церковноприходская школа. - № 1,1887. - С. 48-51, 57-61. 
53. Там же.

54. Сапунов Б. В. «Информационный взрыв» на Руси в XI веке // Русская речь. - 1977. - № 2. - С. 120-128.

55. Костомаров М. І. Галерея портретів. Біогр. нариси. - Київ: Веселка, 1993. - С. 14, 32-34, 51, 120, 266.

56. Гудзий Н.К. История древней русской литературы. - Москва, 1956. - 93 с.

57. Костомаров М. Галерея портретів. Біогр. нариси. - Київ: Веселка, 1993. - С. 14, 32-34, 51, 120, 266.

58. Літературна спадщина Київської Русі і українська література XVI-XVIII ст. - Київ: Наукова думка, 1981. - 268 с.

59. Володимир Мономах. Поучення // Пам'ятники України. - № 3, 1986. - С. 31.

60.Денисенко В.А. Часопис «Киевские епархиальные ведомости» в історії национально-духовного життя України (1861-1918). Науково-довідкове видання / наук. ред. І.І. Дробот; Нац. пед. університет ім. М.П. Драгоманова. - К., 2006. - 692 с.

61. Віктор Андрущенко. Поклик часу і душі / Віктор Андрущенко, Володимир Денисенко. - Київ: Духовна освіта в Україні X-XVIII ст. -518 с.

62. Історія української культури. У 5 т. - Київ: Наукова думка, 2001. - Т. 1. - С. 726; Т. 2. - С. 556, 246-253, 561, 586-591; Т. 3. - С. 612-613.

63. Вишневский Д. Киевская академия в первой половине XVIII столетия. - Київ, 1903. - С. 92-96, 105, 129, 174-175.

64. Енциклопедія українознавства. - Ч. 3.: Загальна частина. - К., 1995. - С. 917-918.

65. Віктор Бондаренко. Симфонія церкви - індикатор світової дипломатії / Віктор Бондаренко, Богдан Андрусишин. // Духовні студії. - К., 2012. - 133 с.

Volodymyr DENYSENKO, Doctor of Historical Sciences, Associate Professor, Head of the Department of Journalism at the Institute of Philology and Mass Communications of the Open International University of Human Development "Ukraine", member of the National Union of Journalists of Ukraine

\section{STATE-FORMING PRINCIPLES OF KYIVAN RUS: SPIRITUALITY, EDUCATION, DIPLOMACY (dedicated to the $1^{2030}{ }^{\text {th }}$ anniversary of Rus-Ukraine baptism)}

Abstract. The author studies the crooked spiritual features of the Kyivan Rus era, juxtaposing them and the mentality of other peoples. The article describes distinctive features of the Christian culture of that time, which, in author's opinion, represents the spiritual image of the era. Historiographical references and literary records of the 11th century are summarized. Primarily, it analyses the chronicle of Nestor the Chronicler, a monk of the Kyiv-Pechersk Monastery; Instructions by Volodymyr Monomakh. A wide range of socio-political, religious and philosophical issues of the then society is defined. The school educational system of that time is described. The author considers the role of Kyivan Rus in European and Middle Eastern history, emphasizing that Kyivan Rus maintained diplomatic relations with a number of European countries and exerted substantial influence on the European history. The historical experience of the achievements of the Christian life in Kyivan Rus is concluded, which will definitely encourage the development of social and religious relations at the current stage.

Keywords: Kyivan Rus, Christianity, cultural and spiritual life, church, educational system. 